\title{
Application of multi-metal stable-isotope-enriched bioassay to assess changes to metal bioavailability in suspended sediments
}

\section{Supporting Information}

Qiuling Wu ${ }^{a \#}$, Tianying Zheng ${ }^{a \#}$, Stuart L. Simpson ${ }^{b, c}$, Qiao-Guo Tan ${ }^{a}$, Rong Chen ${ }^{a}$, Minwei Xie $a^{a^{*}}$

a State Key Laboratory of Marine Environmental Science, Key laboratory of the Ministry of Education for Coastal and Wetland Ecosystem, College of the Environment and Ecology, Xiamen University, Xiamen, Fujian, 361102, China

$b$ Centre for Environmental Contaminants Research, CSIRO Land and Water, Sydney, New South Wales 2334, Australia

c Hong Kong Branch of Southern Marine Science and Engineering Guangdong Laboratory, Hong Kong University of Science and Technology, Clear Water Bay, Hong Kong, China

*Corresponding author

Minwei Xie: minweixie@xmu.edu.cn

\# These two authors contribute equally to the work

Number of pages: 15

Number of Tables: 2

Number of Figures: 7 


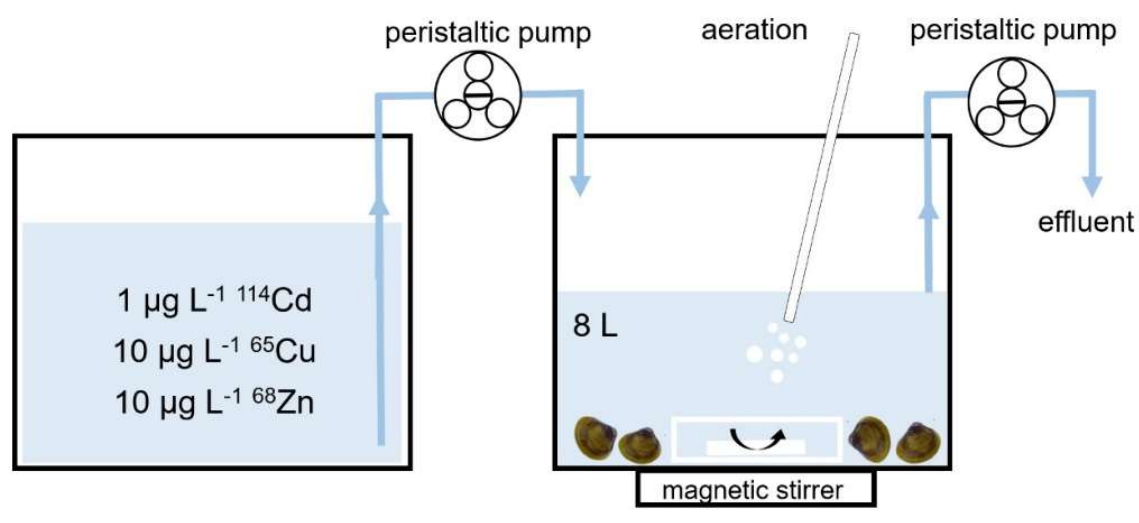

Figure S1. Labeling clams with ${ }^{114} \mathrm{Cd},{ }^{65} \mathrm{Cu}$, and ${ }^{68} \mathrm{Zn}$ in a flow-through system. The exposure chamber (25-L plastic box) contained $8 \mathrm{~L}$ of metal isotope spiked solution and 250 clams. The freshly prepared metal-isotope solution was continuously circulated into and out of the exposure chamber at a rate of $11 \mathrm{~mL} \mathrm{~min}^{-1}$, resulting in a water renewal frequency of twice/day in the exposure chamber. 
(a)

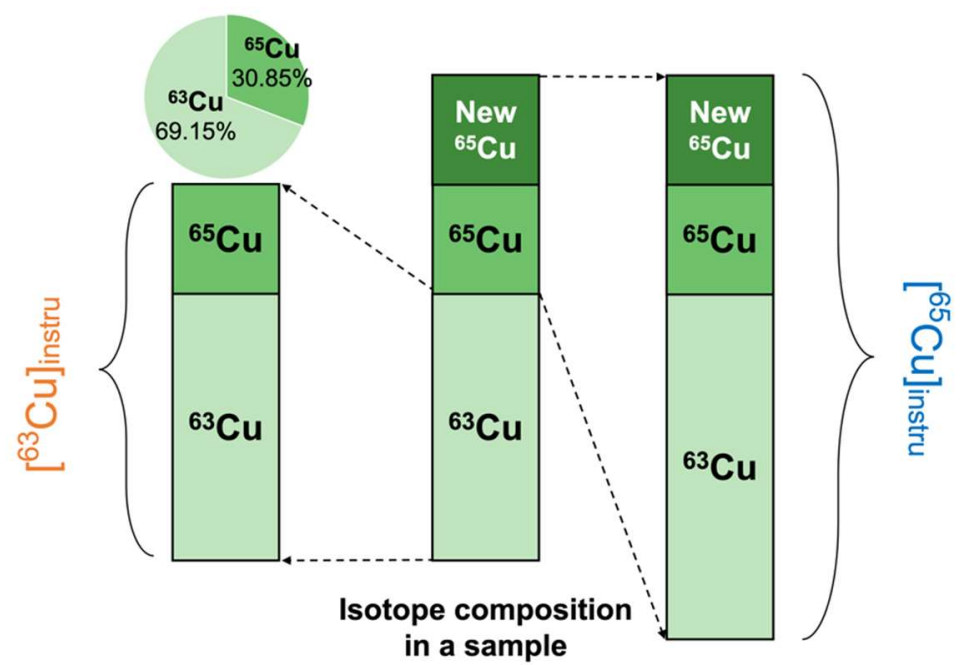

Newly accumulated $\left[{ }^{65} \mathrm{Cu}\right]=\left[{ }^{65} \mathrm{Cu}\right]_{\text {instru }} \times 30.85 \%-\left[{ }^{63} \mathrm{Cu}\right]_{\text {instru }} \times 30.85 \%$

(b)
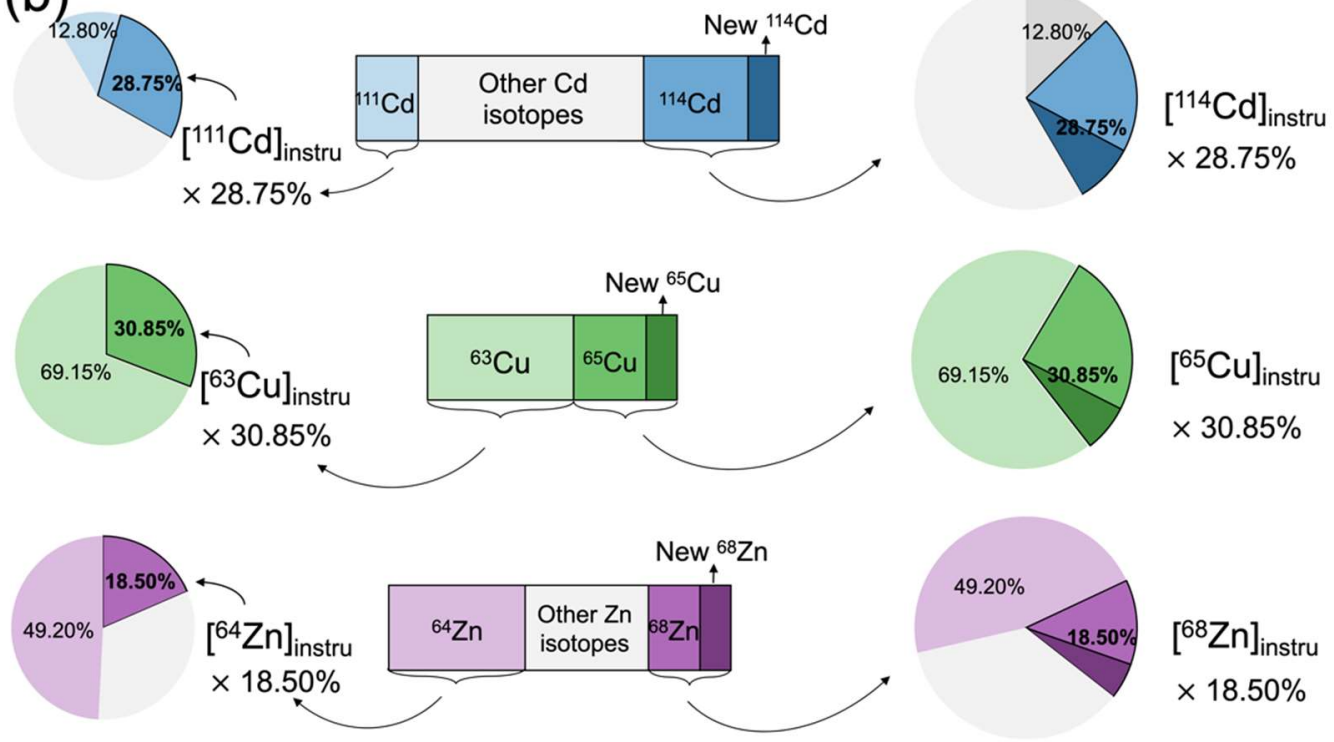

Figure S2. Explanation on how to derive the concentrations of newly accumulated ${ }^{111} \mathrm{Cd},{ }^{65} \mathrm{Cu}$ and ${ }^{64} \mathrm{Zn}$ using the concentrations of different isotopes reported by the ICP-MS instrument. (a) $\mathrm{Cu}$ as an example; (b) Composition of different metal isotopes in a sample. 


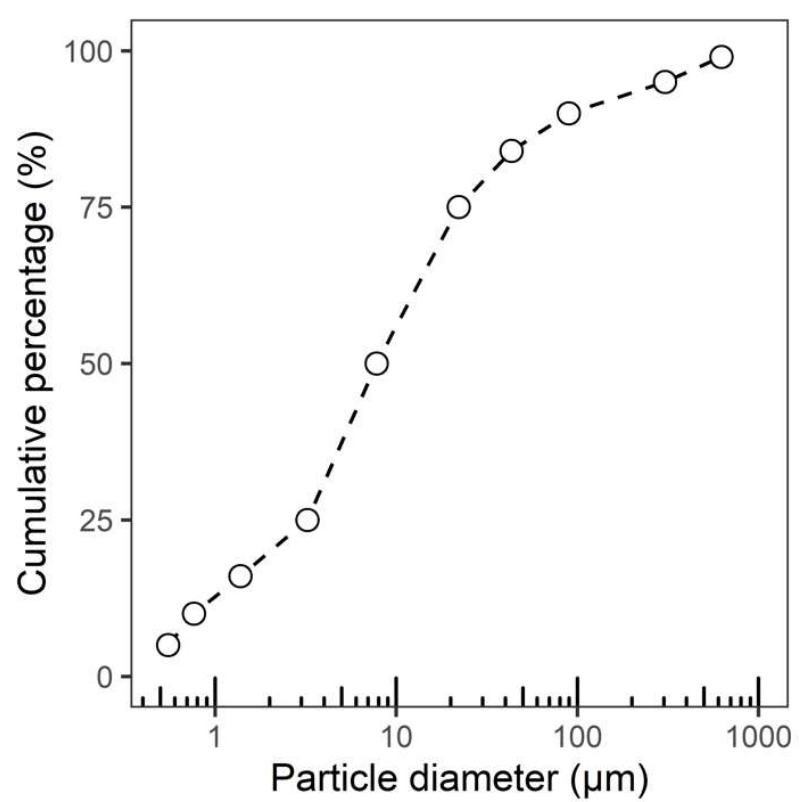

Figure S3. Particle size distribution. 


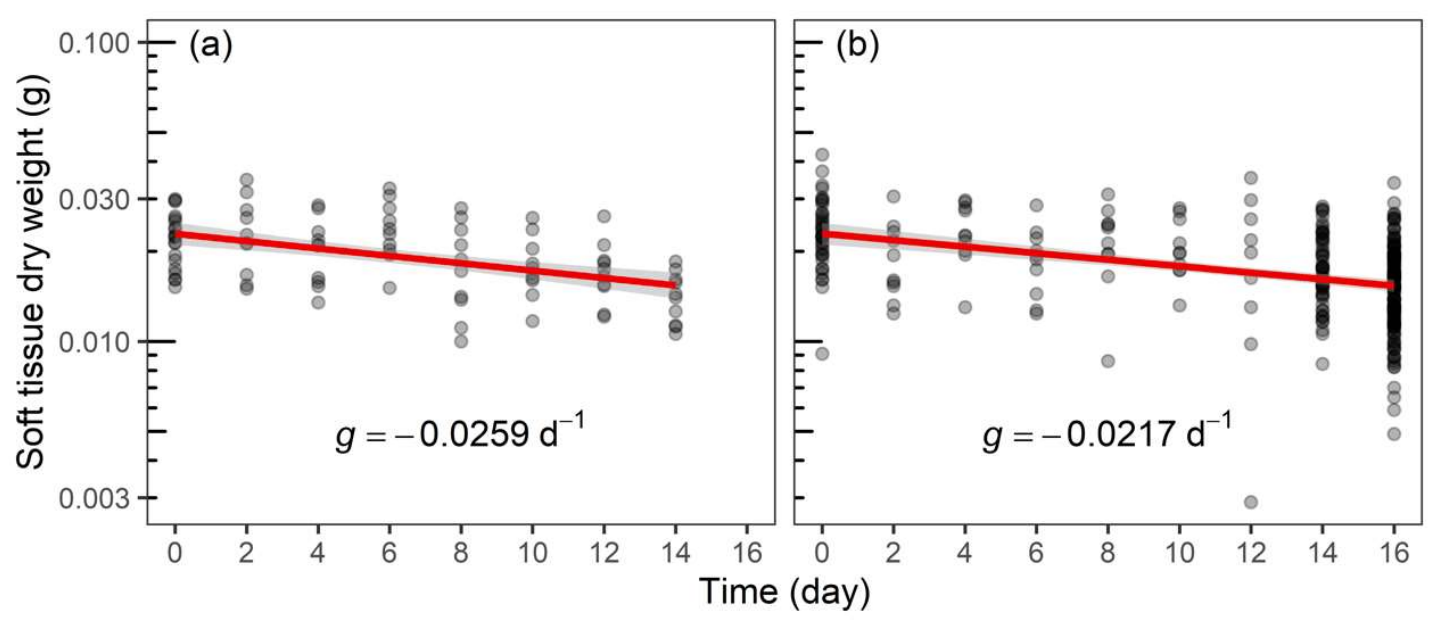

Figure S4. The dry weight of clam soft tissue declined at comparable rates when reared in laboratory (a) in metal spiked water and (b) in clean water. Each point represents the tissue dry weight of an individual clam. Data were fitted with an exponential growth model. ${ }^{1}$ 


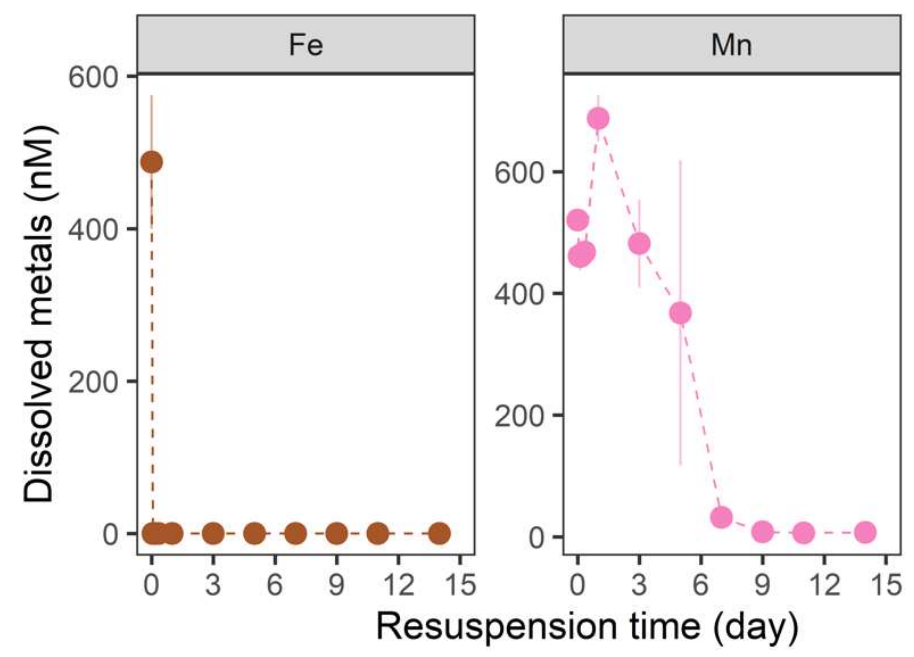

Figure S5. Temporal variation of dissolved iron and manganese in water during sediment resuspension.

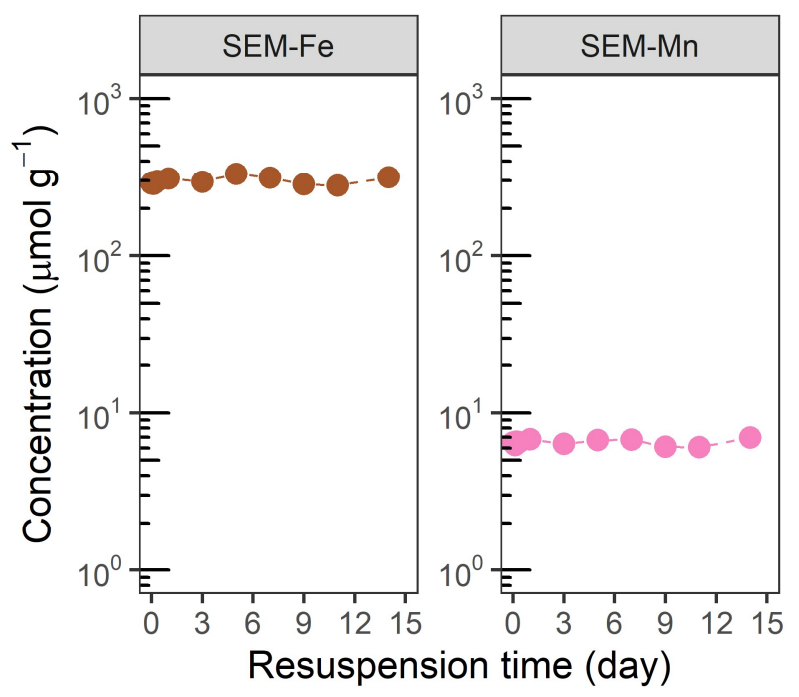

Figure S6. TRM and SEM of iron and manganese remained constant during sediment resuspension. 

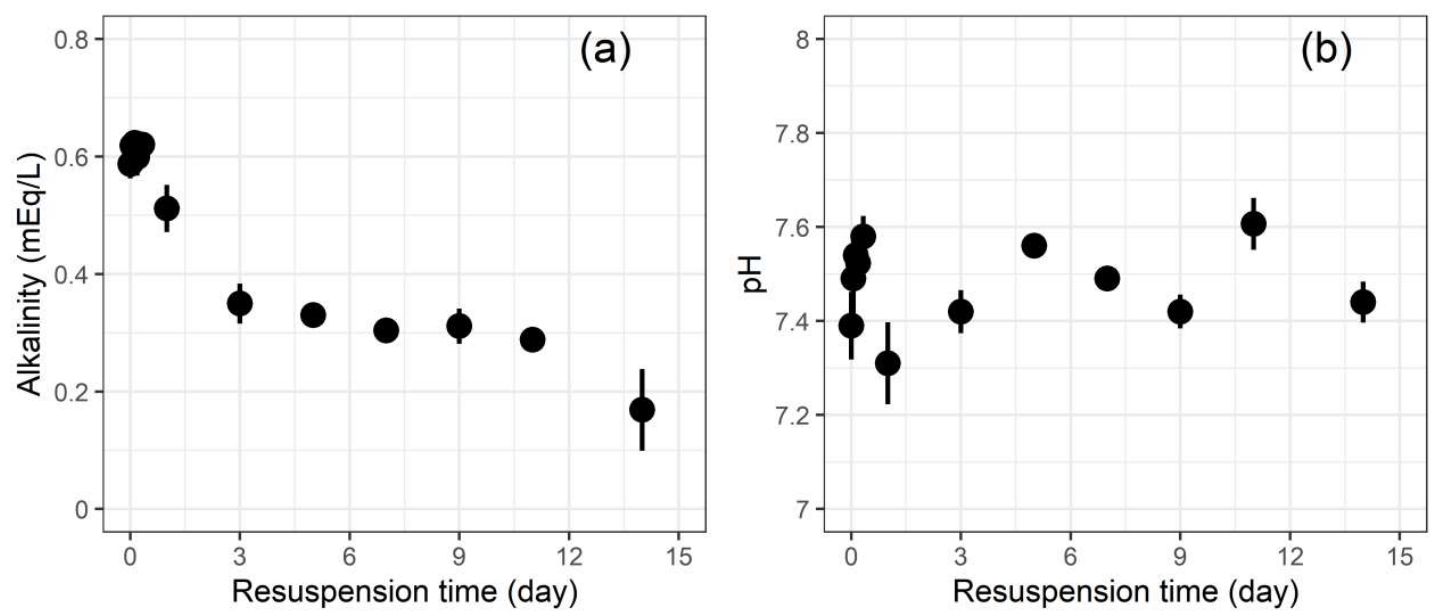

Figure $\mathbf{S 7}$. The changes in alkalinity and $\mathrm{pH}$ during resuspension. 
Table S1. Concentrations of simultaneously extracted metals and total recoverable metals

\begin{tabular}{|c|c|c|c|c|c|c|c|c|c|c|c|c|c|c|c|}
\hline \multirow{2}{*}{$\begin{array}{l}\text { Resuspension } \\
\text { time }\end{array}$} & \multicolumn{5}{|l|}{ SEM } & \multicolumn{5}{|l|}{ TRM } & \multicolumn{5}{|c|}{ SEM/TRM } \\
\hline & $\begin{array}{l}\mathrm{Cu} \\
\mu \mathrm{mol} \mathrm{g}{ }^{-1}\end{array}$ & $\begin{array}{l}\mathrm{Zn} \\
\mu \mathrm{mol} \mathrm{g}{ }^{-1}\end{array}$ & $\begin{array}{l}\mathrm{Cd} \\
\mathrm{nmol} \mathrm{g}{ }^{-1}\end{array}$ & $\begin{array}{l}\mathrm{Fe} \\
\mu \mathrm{mol} \mathrm{g}{ }^{-1}\end{array}$ & $\begin{array}{l}\mathrm{Mn} \\
\mu \mathrm{mol} \mathrm{g}\end{array}$ & $\begin{array}{l}\mathrm{Cu} \\
\mu \mathrm{mol} \mathrm{g}{ }^{-1}\end{array}$ & $\begin{array}{l}\mathrm{Zn} \\
\mu \mathrm{mol} \mathrm{g}-1\end{array}$ & $\begin{array}{l}\mathrm{Cd} \\
\mathrm{nmol} \mathrm{g}^{-1}\end{array}$ & $\begin{array}{l}\mathrm{Fe} \\
\mu \mathrm{mol} \mathrm{g}-1\end{array}$ & $\begin{array}{l}\mathrm{Mn} \\
\mu \mathrm{mol} \mathrm{g}-1\end{array}$ & $\mathrm{Cu}$ & $\mathrm{Zn}$ & $\mathrm{Cd}$ & $\mathrm{Fe}$ & $\mathrm{Mn}$ \\
\hline $0.1 \mathrm{~h}$ & $6.6 \pm 0.7$ & $9.4 \pm 0.0$ & $13 \pm 0$ & $290 \pm 10$ & $6.5 \pm 0.0$ & $30 \pm 2$ & $19 \pm 1$ & $20 \pm 1$ & $890 \pm 30$ & $10 \pm 1$ & $22 \%$ & $50 \%$ & $66 \%$ & $33 \%$ & $65 \%$ \\
\hline $1.5 \mathrm{~h}$ & $16 \pm 1$ & $13 \pm 0$ & $18 \pm 0$ & $290 \pm 20$ & $6.5 \pm 0.3$ & $31 \pm 2$ & $20 \pm 1$ & $20 \pm 1$ & $920 \pm 40$ & $9.9 \pm 0.4$ & $53 \%$ & $64 \%$ & $88 \%$ & $32 \%$ & $65 \%$ \\
\hline $3 \mathrm{~h}$ & $18 \pm 1$ & $13 \pm 0$ & $18 \pm 1$ & $290 \pm 10$ & $6.3 \pm 0.2$ & I & I & I & / & I & I & / & I & / & I \\
\hline $4.5 \mathrm{~h}$ & $18 \pm 1$ & $14 \pm 1$ & $19 \pm 2$ & $290 \pm 10$ & $6.6 \pm 0.0$ & I & I & I & / & I & I & / & I & / & I \\
\hline $8 \mathrm{~h}$ & $18 \pm 1$ & $14 \pm 1$ & $17 \pm 0$ & $300 \pm 0$ & $6.5 \pm 0.1$ & I & / & I & / & I & I & / & I & / & I \\
\hline $1 \mathrm{~d}$ & $20 \pm 1$ & $14 \pm 0$ & $19 \pm 0$ & $310 \pm 0$ & $6.8 \pm 0.1$ & $31 \pm 1$ & $20 \pm 2$ & $19 \pm 1$ & $950 \pm 20$ & $10 \pm 0$ & $67 \%$ & $73 \%$ & $98 \%$ & $33 \%$ & $66 \%$ \\
\hline $3 d$ & $21 \pm 1$ & $14 \pm 1$ & $18 \pm 2$ & $300 \pm 20$ & $6.4 \pm 0.3$ & $30 \pm 1$ & $19 \pm 1$ & $18 \pm 3$ & $880 \pm 10$ & $10 \pm 0$ & $71 \%$ & $75 \%$ & $98 \%$ & $34 \%$ & $66 \%$ \\
\hline $7 d$ & $25 \pm 1$ & $15 \pm 0$ & $18 \pm 0$ & $310 \pm 10$ & $6.8 \pm 0.2$ & $27 \pm 3$ & $18 \pm 1$ & $20 \pm 1$ & $830 \pm 70$ & $9.4 \pm 0.8$ & $93 \%$ & $85 \%$ & $94 \%$ & $38 \%$ & $72 \%$ \\
\hline $9 \mathrm{~d}$ & $24 \pm 1$ & $15 \pm 1$ & $18 \pm 1$ & $280 \pm 10$ & $6.1 \pm 0.3$ & $30 \pm 3$ & $18 \pm 1$ & $21 \pm 0$ & $890 \pm 60$ & $10 \pm 1$ & $80 \%$ & $82 \%$ & $85 \%$ & $32 \%$ & $61 \%$ \\
\hline $11 \mathrm{~d}$ & $23 \pm 0$ & $14 \pm 1$ & $18 \pm 1$ & $280 \pm 0$ & $6.1 \pm 0.3$ & $30 \pm 4$ & $18 \pm 3$ & $19 \pm 3$ & $870 \pm 140$ & $9.9 \pm 1.3$ & $78 \%$ & $78 \%$ & $97 \%$ & $32 \%$ & $61 \%$ \\
\hline $14 \mathrm{~d}$ & $26 \pm 0$ & $15 \pm 0$ & $19 \pm 1$ & $320 \pm 0$ & $7.0 \pm 0.1$ & $27 \pm 3$ & $19 \pm 6$ & $14 \pm 17$ & $840 \pm 110$ & $9.6 \pm 1.0$ & $95 \%$ & $77 \%$ & $134 \%$ & $37 \%$ & $73 \%$ \\
\hline
\end{tabular}


Table S2. Cadmium assimilated from sediments resuspended for differing time

\begin{tabular}{cc}
\hline $\begin{array}{c}\text { Resuspension } \\
\text { duration (d) }\end{array}$ & $\begin{array}{c}\text { Cadmium } \\
\text { assimilated (ng) }\end{array}$ \\
\hline 0.1 & 1.4 \\
1 & 2.8 \\
3 & 4.2 \\
7 & 4.8 \\
14 & 7.1 \\
\hline
\end{tabular}




\section{Note S1. Detailed procedures for analysis of water, sediment and organism}

Filtered water samples from the resuspension experiments were analyzed for $\mathrm{pH}$, alkalinity, and dissolved sulfate concentrations. The $\mathrm{pH}$ was measured using a $\mathrm{pH}$ meter (FE28 standard, electrode model LE438, Mettler Toledo). Alkalinity was determined colorimetrically using the formic acid-bromophenol blue method. ${ }^{2}$ The dissolved sulfate concentration was determined using an Ion Chromatography system (ICS 1100, Thermo Fisher Scientific Inc.) equipped with an anion exchange chromatography column (AS19).

Sediment samples were characterized for particle size distribution, and analyzed for total recoverable metals (TRM), acid volatile sulfide (AVS) and simultaneously extracted metals (SEM). The particle size distribution was determined using a particle sizer (Mastersizer 3000, Malvern Instruments). TRM was determined by digesting dried sediments (ca. $0.074 \mathrm{~g}$ ) in $2 \mathrm{~mL}$ of concentrated $\mathrm{HNO}_{3}$ at room temperature overnight and then at $120^{\circ} \mathrm{C}$ for $7.5 \mathrm{~h}$, and measuring metal concentrations in the extractant. ${ }^{3}$ AVS and SEM were determined following the purge-and-trap method. ${ }^{4}$ Briefly, $50 \mathrm{~mL}$ of sediment slurry was purged in the extraction system under a stream of $\mathrm{N}_{2}$ gas flow to remove dissolved oxygen; $10 \mathrm{~mL}$ of $6 \mathrm{M} \mathrm{HCl}$ solution was then added to achieve an equivalent concentration of $1 \mathrm{M}$ and sediment was extracted for $50 \mathrm{~min}$; the extracted $\mathrm{H}_{2} \mathrm{~S}$ was trapped in $0.5 \mathrm{M} \mathrm{NaOH}$ and determined colorimetrically, and metal concentrations simultaneously extracted were measured. 


\section{Note S2. Calculation of newly accumulated metal isotope concentrations}

The ICP-MS instrument reports concentrations of different metal isotopes by assuming that the isotopic composition of a sample is the same as that of the calibration standards. Namely, the measured signal of each metal isotope was converted to the reported concentrations ([$\left.{ }^{\mathrm{xx}} \mathrm{Me}\right]$ instru) by dividing the natural abundance of this isotope (assuming that the calibration standards have a natural isotopic abundance of different metals). Therefore, the concentration of metal isotopes newly accumulated during the labeling stage can be calculated using the reported concentrations of different metal isotopes (Figure S2).

Taking the calculation of newly accumulated ${ }^{65} \mathrm{Cu}$ as an example (Figure S2a), the composition of $\mathrm{Cu}$ in a clam tissue sample includes three fractions: the "old" ${ }^{63} \mathrm{Cu}$ fraction, the "old" ${ }^{65} \mathrm{Cu}$ fraction that varies with the "old" ${ }^{63} \mathrm{Cu}$ fraction during the labeling process, and the newly accumulated ${ }^{65} \mathrm{Cu}$ fraction. When this sample is analyzed using the ICP-MS, the instrument reported concentration inferred from the isotope ${ }^{63} \mathrm{Cu}\left(\left[{ }^{63} \mathrm{Cu}\right]_{\text {instru }}\right)$ equals to the sum of the "old" ${ }^{63} \mathrm{Cu}$ fraction and the "old" ${ }^{65} \mathrm{Cu}$ fraction; the instrument reported concentration inferred from the isotope ${ }^{65} \mathrm{Cu}$ $\left(\left[{ }^{65} \mathrm{Cu}\right]\right.$ instru $)$ includes the "old" ${ }^{65} \mathrm{Cu}$ fraction, the newly accumulated ${ }^{65} \mathrm{Cu}$ fraction and an inferred ${ }^{63} \mathrm{Cu}$ fraction. Accordingly, the newly accumulated $\left[{ }^{65} \mathrm{Cu}\right]$ can be calculated as the difference between $\left[{ }^{65} \mathrm{Cu}\right]_{\text {instru }} \times 30.85 \%$ and $\left[{ }^{63} \mathrm{Cu}\right]_{\text {instru }} \times 30.85 \%$.

Similarly, the newly accumulated concentrations of other metal isotopes can also be calculated in the same manner (Figure S2b), and the equations are shown as Equation 1-3 in the manuscript. The isotopic ratio of each metal can also be calculated as Equation 4-6 in the manuscript. 


\section{Note S3. Calculation of approach sensitivity}

The isotopic ratio in the control group was considered as a baseline, assimilation of bioavailable metals from sediment particles would drop the isotopic ratio. The isotopic ratio of $\mathrm{Cd}^{114 / 111}, \mathrm{Cu}^{65 / 63}$ and $\mathrm{Zn}^{68 / 64}$ in the control group was 55.4, 2.39 and 0.544 respectively. Assuming that $x \mathrm{ng} \mathrm{Cd}, y \mathrm{ng} \mathrm{Cu}$ and $z \mathrm{ng} \mathrm{Zn}$ has been assimilated to cause a $10 \%$ drop in the isotopic ratios, the following equations can be solved to estimate the three unknown variables $x, y$ and $z$.

$$
\begin{aligned}
& \frac{D W \times\left[{ }^{114} \mathrm{Cd}\right]_{\text {instru }} \times 28.75 \%+x \cdot 28.75 \%}{D W \times\left[{ }^{111} \mathrm{Cd}\right]_{\text {instru }} \times 12.8 \%+x \cdot 12.8 \%}=55.4 \times 90 \% \\
& \frac{D W \times\left[{ }^{65} \mathrm{Cu}\right]_{\text {instru }} \times 30.85 \%+y \cdot 30.85 \%}{D W \times\left[{ }^{63} \mathrm{Cu}\right]_{\text {instru }} \times 69.15 \%+y \cdot 69.15 \%}=2.39 \times 90 \% \\
& \frac{D W \times\left[{ }^{68} \mathrm{Zn}\right]_{\text {instru }} \times 18.5 \%+z \cdot 18.5 \%}{D W \times\left[{ }^{64} \mathrm{Zn}\right]_{\text {instru }} \times 49.2 \%+z \cdot 49.2 \%}=0.544 \times 90 \%
\end{aligned}
$$

where $D W$ is the dry weight of the clam, $\left[{ }^{114} \mathrm{Cd}\right]_{\text {instru }},\left[{ }^{111} \mathrm{Cd}\right]_{\text {instru }}$, $\left[{ }^{65} \mathrm{Cu}\right]_{\text {instru }},\left[{ }^{63} \mathrm{Cu}\right]_{\text {instru }}, \quad\left[{ }^{68} \mathrm{Zn}\right]_{\text {instru }}$, and $\left[{ }^{64} \mathrm{Zn}\right]_{\text {instru }}$ are the total metal concentrations reported by the ICP-MS instrument, which are derived from the measured signal of each isotope assuming that each element has a natural abundance; the numbers $28.75 \%, 12.80 \%, 30.85 \%, 69.15 \%, 18.5 \%$, and $49.20 \%$ are the natural isotope abundance of ${ }^{114} \mathrm{Cd},{ }^{111} \mathrm{Cd},{ }^{65} \mathrm{Cu},{ }^{63} \mathrm{Cu},{ }^{68} \mathrm{Zn}$, and ${ }^{64} \mathrm{Zn}$.

With three equations and three unknown variables, we can calculate the value of $x$, $y$ and $z$. They are 2.0,26, and 1300 respectively, and are referred to as the approach sensitivity in the manuscript. 


\section{Note S4: Interpretation of metal sulfide oxidation from sulfate release and changes in AVS and SEM}

The rapid sulfate release over the first $8 \mathrm{~h}$ was $\sim 0.32 \mathrm{mmol} \mathrm{SO}_{4}^{2-}$ into the water ( $24 \%$ of the total $\mathrm{SO}_{4}{ }^{2-}$ produced, i.e. $1.32 \mathrm{mmol}$ ), which may be primarily due to iron sulfide (FeS) oxidation that typically is the dominant monosulfide phase in sediments. ${ }^{5-7}$ The AVS concentrations were initially $19 \pm 5 \mu \mathrm{mol} \mathrm{g}{ }^{-1}$, substantially lower than that of the bulk sediment $\left(45 \pm 15 \mu \mathrm{mol} \mathrm{g}{ }^{-1}\right)$. This loss may be attributed to oxidation of sediments during experimental operation (e.g. rapid homogenization and weighing processes) and the oxidation in water following the commencement of resuspension (ca. $10 \mathrm{~min}$ ) before the first sample was measured. The AVS concentration then further rapidly decreased from $19 \pm 5$ to $<0.5 \mu \mathrm{mol} \mathrm{g} \mathrm{g}^{-1}$ within 3 days with greater than $90 \%$ of the AVS loss occurring within the first 8 hour (Figure 4). Assuming all AVS was converted to sulfate by oxidation during the resuspension period, the loss of the AVS $(\times 7 \mathrm{~g}$ dry weight) induced release of $0.30 \mathrm{mmol}$ dissolved sulfate, accounting for ca. $94 \%$ of the sulfate produced over the first $8 \mathrm{~h}$ (Figure 4).

The metals simultaneously extracted during the AVS measurement showed different temporal variations (Figure 4 and Figure S6). SEM-Fe and SEM-Mn were constant with time over the course of experiment, each representing $34 \%$ and $67 \%$ of total recoverable Fe and Mn (TRM, Figure S6). This is consistent with the primary source of SEM-Fe and -Mn coming from monosulfide phases that are readily dissolved in the AVS extraction $(50 \mathrm{~min}, 1 \mathrm{M} \mathrm{HCl})$, where the observation that the separation between the iron concentrations measured as SEM $(300 \pm 30 \mu \mathrm{mol} \mathrm{Fe} / \mathrm{g})$ and TRM $(910 \pm 90 \mu \mathrm{mol} \mathrm{Fe} / \mathrm{g})$ indicated that little of the more crystalline iron sulfide phases were dissolving over the 14 day period..$^{8,9}$

The SEM-Cd and SEM-Zn concentrations increased rapidly from 13 to $18 \mathrm{nmol}$ $\mathrm{g}^{-1}$ and from 9.4 to $13 \mu \mathrm{mol} \mathrm{g}^{-1}$ within the first $8 \mathrm{~h}$, respectively, and remained constant for the remaining days of experiment. In contrast, the SEM-Cu concentrations showed different temporal variations. Both $\mathrm{CdS}$ and $\mathrm{ZnS}$ are fully extracted in the AVS procedure, while less than $30 \%$ of copper from $\mathrm{CuS}$ or $\mathrm{Cu}_{2} \mathrm{~S}$ is extracted and the amount extracted is influenced by the dissolved ferric iron 
concentrations. ${ }^{6,9}$ The SEM-Cu rapidly increased from 6.6 to $16 \mu \mathrm{mol} \mathrm{g}{ }^{-1}$ for the first 1.5 hour and then further to $24 \mu \mathrm{mol} \mathrm{g} \mathrm{g}^{-1}$ at day 5 , and remained constant over the following 9 days. As a result, the SEM-Cu gradually approached the TRM-Cu with resuspension time - the SEM-Cu/TRM-Cu ratio gradually increased from 0.22 at day 0 to 0.95 at day 14 (Table S1). This observation of dynamic change in copper speciation is consistent with the oxidation of copper sulfide phases $\left(\mathrm{CuS}, \mathrm{Cu}_{2} \mathrm{~S}\right)$, which occurs much more slowly than the oxidation of other metal sulfide phases, typically in the order of $\mathrm{FeS}>\mathrm{MnS}>>\mathrm{CdS}, \mathrm{ZnS}>\mathrm{CuS} / \mathrm{Cu}_{2} \mathrm{~S}{ }^{6}$

Due to the strong binding between copper ion and sulfide, pure copper sulfide mineral does not dissolve in $1 \mathrm{M} \mathrm{HCl}$ and $\mathrm{Cu}^{2+}$ cannot be extracted when AVS analysis was performed. However, when Fe(III) is present at extraction, oxidation of sulfide to $\mathrm{SO}_{4}^{2-}$ or $\mathrm{S}^{0}$ can (partially) occur. ${ }^{6}$ Therefore, SEM-Cu can be detected but no $\mathrm{H}_{2} \mathrm{~S}$ is produced (i.e. no corresponding AVS measured). This Fe(III) catalytic copper sulfide extraction was reported to be dependent of Fe(III) concentration at low $\mathrm{Fe}(\mathrm{III})$ system $(\mathrm{Fe}(\mathrm{III}) / \mathrm{SEM}-\mathrm{Cu}<2)$ but became independent on $\mathrm{Fe}(\mathrm{III})$ concentration when $\mathrm{Fe}(\mathrm{III})$ was sufficient. ${ }^{6}$ Observation of SEM-Cu $\left(6.6 \mu \mathrm{mol} \mathrm{g} \mathrm{g}^{-1}\right)$ in sediments at the beginning of resuspension may thus be attributed to the Fe(III) facilitated partial extraction of copper sulfide.

Given that $\mathrm{Fe}(\mathrm{II}) \mathrm{S}$ was oxidized rapidly in neutral condition, ${ }^{5,} 6 \mathrm{Fe}(\mathrm{III})$ (as hydroxide phases) in the sediment slurry was adequately high (SEM-Fe/TRM-Cu >9) and invariant with time (Figure S6). The extractability of SEM-Cu thus should be independent of $\mathrm{Fe}(\mathrm{III})$ in sediments. Therefore, the gradual increase of SEM-Cu with resuspension time suggests that oxidation of copper sulfide produced more extractable copper species over the course of resuspension. Assuming that copper was predominantly in the monosulfide phase $(\mathrm{CuS})$, this results in $0.17 \mathrm{mmol}$ of sulfide being oxidized ( $24 \mu \mathrm{mol} \mathrm{g} \mathrm{g}^{-1} \times 7 \mathrm{~g}$ dry weight), accounting for ca. $13 \%$ of produced $\mathrm{SO}_{4}{ }^{2-}$ (the net release of $\mathrm{SO}_{4}{ }^{2-}$ is $1.32 \mathrm{mmol}$ ), or half that amount for sulfate from oxidation of $\mathrm{Cu}_{2} \mathrm{~S}$. 


\section{REFERENCES}

1. Lin, Z.; Fan, X.; Huang, J.; Chen, R.; Tan, Q.-G., Intertidal mussels do not stop metal bioaccumulation even when out of water: Cadmium toxicokinetics in Xenostrobus atratus under influences of simulated tidal exposure. Environmental Pollution 2020, 261, 114192.

2. Sarazin, G.; Michard, G.; Prevot, F., A rapid and accurate spectroscopic method for alkalinity measurements in sea water samples. Water Res 1999, 33, (1), 290-294.

3. Sastre, J.; Sahuquillo, A.; Vidal, M.; Rauret, G., Determination of $\mathrm{Cd}, \mathrm{Cu}, \mathrm{Pb}$ and $\mathrm{Zn}$ in environmental samples: microwave-assisted total digestion versus aqua regia and nitric acid extraction. Analytica Chimica Acta 2002, 462, (1), 59-72.

4. Allen, H.; Fu, G.; Boothman, W.; Di Toro, D.; Mahony, J. Determination of acid volatile sulfide and selected simultaneously extractable metals in sediment; Office of Water Regulations and Standards: US Environmental Protection Agency, Washington, DC, 1991.

5. Di Toro, D. M.; Mahony, J. D.; Gonzalez, A. M., Particle oxidation model of synthetic FeS and sediment acid - volatile sulfide. Environmental Toxicology and Chemistry 1996, 15, (12), 2156-2167.

6. Simpson, S. L.; Apte, S. C.; Batley, G. E., Effect of short-term resuspension events on trace metal speciation in polluted anoxic sediments. Environmental Science \& Technology 1998, 32, (5), 620-625.

7. USEPA, Procedures for the derivation of equilibrium partitioning sediment benchmarks (ESBs) for the protection of benthic organisms: Metal mixtures (cadmium, copper, lead, nickel, silver, and zinc). In US Environmental Protection Agency, Office of Research and Development: Washington, DC, USA., 2005.

8. Rickard, D.; Morse, J. W., Acid volatile sulfide (AVS). Marine Chemistry 2005, 97, (3), 141-197.

9. Cooper, D. C.; Morse, J. W., Biogeochemical controls on trace metal cycling in anoxic marine sediments. Environmental Science \& Technology 1998, 32, (3), 327-330. 